\title{
THE USE OF BORATE BUFFER IN PAPER ELECTROPHORESIS OF SERUM
}

\author{
BY \\ R. CONSDEN AND MYFANWY N. POWELL \\ From the Canadian Red Cross Memorial Hospital, Taplow, Maidenhead, Berks
}

(RECEIVED FOR PUBLICATION DECEMBER 23, 1954)

Electrophoresis of sera on filter paper is usually carried out in barbitone buffer. There are few references to the use of borate buffer, and, since we have observed that in this buffer the $\beta$-globulin components are better differentiated, it is considered of interest to record some of our observations.

\section{Methods}

Conditions of Electrophoresis.-The apparatus used was similar to that described by Franglen (1953). It consisted of a flat shallow "perspex" box in which a sheet of Whatman No. 1 paper was stretched horizontally with the ends dipping into the electrode solutions. The paper was first wetted with electrolyte, blotted, and placed in position in the apparatus. Serum (10 $\mu \mathrm{l}$.) was then applied from a micropipette along a length of about $2.7 \mathrm{~cm}$. of the starting line, which was placed towards the cathode end. The voltage applied was $14-15 \mathrm{~V} / \mathrm{cm}$. for two and a half to three hours and average current varied with the nature of the buffer used but in most experiments was $0.4-0.5 \mathrm{~mA} / \mathrm{cm}$. width. Electrophoresis was carried out at room temperature; the paper strips were dyed with bromphenol blue according to Kunkel and Tiselius (1951).

Buffer Solutions.-All buffers had $p \mathrm{H} 8.6$ (glass electrode). The three buffers used in this investigation were (1) $0.05 \mathrm{M}$ barbitone as described by Durrum (1950); (2) $0.2 \mathrm{M}$ borate buffer, prepared by mixing $0.2 \mathrm{M}$ boric acid ( $3.5 \mathrm{vol}$.) with $0.2 \mathrm{M}$ sodium hydroxide (1 vol.); (3) borate-barbitone buffer prepared by mixing equal volumes of (1) with $0.1 \mathrm{~m}$ borate buffer. The latter was half strength buffer (2).

\section{Results}

In this investigation all runs were carried out with samples of the same serum from a normal adult female. Except for the ageing experiment (see below), the serum was stored at $-20^{\circ} \mathrm{C}$. when not required. When electrophoresis was carried out soon after collecting the blood and preparing the serum, two distinct bands were observed in the $\beta$-globulin region when borate was the buffer used. This is illustrated in Fig. 1A. The strongest band $\left(\beta_{1}\right)$ had a mobility about 0.4 that of the albumin $\stackrel{0}{0}$ as measured from the $\gamma$ globulin band. The slower $N$ $\beta$-globulin band $\left(\beta_{2}\right)$ was relatively fainter in colour $\vec{f}$ and of a greyer shade than the $\beta_{1}$. In barbitone buffer, when electrophoresis was carried out immediately following the borate electrophoresis, separa- $\vec{z}$ tion of these two was much less clearly defined (Fig. 1B), the mobility of the $\beta$ band being similar in this buffer to that of $\beta_{1}$ in borate. When samples $\mathcal{E}$ of the serum were allowed to stand at room temperature for several hours, the $\beta_{2}$ band became much fainter in borate buffer and after 24 hours had disappeared. The electrophoretic pattern then only showed one $\beta$ band and the disappearance of $\approx$ the slower component was accompanied by an $\stackrel{\mathbb{Q}}{\Omega}$ increase in depth of colour of the remaining $\beta_{1} \overrightarrow{\vec{P}}$ band. Refrigeration of the serum failed to stabilize $\frac{3}{3}$ the $\beta_{2}$ component, though it disappeared much more slowly than when the serum was kept at room temperature. After 10 days at $-20^{\circ}$ C. the $\beta_{2}$ band was very faint. If the serum was aged sufficiently a third component $\left(\beta_{\Delta}\right)$, just faster and $\frac{5}{3}$ relatively fainter than the $\beta_{1}$ band, appeared. This is illustrated in Fig. 1C, which is the electrophoretic $ᄋ$ pattern in borate buffer of the serum after keeping for 48 hours at room temperature. In barbitone 9 buffer, however, this aged serum gave only one $\frac{}{2}$ $\beta$ globulin band (Fig. 1D).

Short periods of electrophoresis were found $N_{\sigma}$ necessary to demonstrate the presence of the slower, labile $\beta_{2}$ component in fresh serum. With prolonged periods, e.g., for 17 hours at 3 volts $/ \mathrm{cm}$., $\omega$ after which the albumin had travelled through a similar distance as in the shorter period at the higher voltage, it was no longer visible. However, $\mathbb{D}$ the $\beta_{A}$ band of the serum aged 48 hours was present ${ }^{+}$ under these conditions.

Other non-borate buffers of $p \mathrm{H} 8.6$ were investi- $\frac{\text { ते }}{\mathbb{S}}$ gated; e.g., glycine-sodium hydroxide, citrate and $\frac{\mathcal{P}}{\mathbb{Q}}$ phosphate; but these were similar to barbitone in $\cong$ their effect on the $\beta$-globulins. Borate buffer hase 


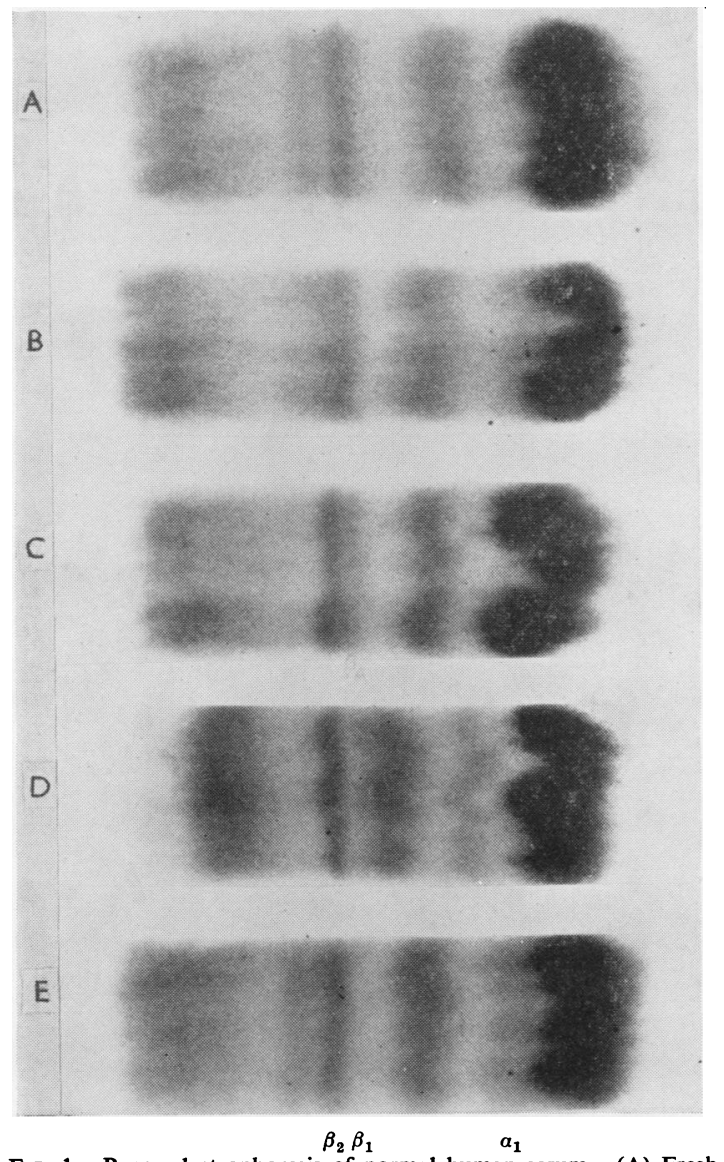

FIG. 1.-Paper electrophoresis of normal human serum. (A) Fresh serum in borate buffer, (B) the same in barbitone buffer, (C) 48hour-old serum in borate buffer, (D) the same in barbitone buffer, (E) fresh serum in borate-barbitone buffer.

the disadvantage of increasing the mobility of $a_{1}$-globulin to that of albumin, but this was overcome by employing the mixed borate-barbitone buffer, which also differentiated the $\beta$ components of fresh or aged serum as satisfactorily as borate alone. This is illustrated for the fresh serum in Fig. 1E. This electrophoresis was carried out on the day following the electrophoresis in barbitone, the serum in the meantime being stored at $-20^{\circ} \mathrm{C}$.

\section{Discussion}

The mixed borate-barbitone buffer has been used for some considerable time in these laboratories for the routine examination of sera, and the double band as illustrated in Fig. 1E has always been present provided the sera are examined within one to two hours after the collection of the blood, or if stored at $-20^{\circ}$ C. for a few days. Sera kept for more than several hours at room temperature generally give only one $\beta$ band, but occasionally we have observed all three bands $\left(\beta_{1}, \beta_{2}\right.$, and $\left.\beta_{\mathrm{A}}\right)$. It is clear from these observations and from the experiments described above that the $\beta_{2}$ component is very labile and is rapidly converted, probably by enzyme action, to a protein of higher mobility. On the other hand the faster component $\left(\beta_{\mathrm{A}}\right)$ of the aged serum is stable and would seem to be an artefact derived from one of the $\beta_{1}$ - or $\beta_{2}$-globulins. These changes would of course be taking place during the course of electrophoresis, which would explain the disappearance of the $\beta_{2}$ band after long periods of electrophoresis. Of the many photographs of paper electrophoresis strips of serum which we have seen, the great majority show only one $\beta$ band. This is in agreement with our finding that the labile component is not well separated in barbitone buffer. However, we have observed a few examples which show distinct separation of the $\beta_{1}, \beta_{2}$ components in this buffer. For example, these two bands were observed in pathological sera by Grassmann (1951) and Kawerau (1954) and in normal sera by Antonini and Piva (1953). Occasionally also the third component, similar to the artefact $\beta_{A}$, has been observed (cf. Kawerau, 1954), but the infrequency of these examples suggests that it is exceptional to obtain more than one definite $\beta$ band in non-borate buffer. As far as our experiments are concerned, it would appear that borate ions are specifically concerned in altering the mobilities of some of the $\beta$-globulins. It is well known that borate ions can form complexes with substances containing $a$-glycol groups and therefore alter their electrophoretic mobilities. Groups of this type occur in many carbohydrates and lipids, and, since these (especially the latter) occur with the $\beta$-globulins, alteration of some of the components by borate might be expected. It is not clear, however, why the $\beta_{2}$ component should become slower, since borate complexing usually confers extra negative charges and therefore higher mobility, as is the case with the $\beta_{\mathrm{A}}$ component and $\alpha_{1}$-globulin.

Owing to the transient nature of the $\beta_{2}$-globulin, it has not yet been possible to correlate any variations in its strength with any particular pathological condition, but this could well be of significance in certain cases, and any method, such as the use of borate, which improves separation in the highly complex $\beta$-globulin region is clearly desirable.

\section{Summary}

In borate buffer, one of the $\beta$-globulins of fresh, normal human serum has a lower electrophoretic mobility and after paper electrophoresis is separated 
as a relatively faint band from the band of the other $\beta$-globulins. Separation in non-borate buffers is less satisfactory.

The component of lower mobility is converted, after a few hours at room temperature, to one with a mobility similar to that of the other $\beta$-globulins. After sufficient ageing, one of the $\beta$-globulins is converted to a component which, in borate, travels somewhat ahead of the $\beta$-globulin band, but it is not separated in barbitone.
Borate-barbitone buffer combines the advantages of borate and barbitone.

\section{REFERENCES}

Antonini, F. M., and Piva, G. (1953). Recenti Progr. Med., 14, 243.

Durrum, E. L. (1950). J. Amer. chem. Soc., 72, 2943.

Franglen, G. T. (1953). Journal of Clinical Pathology, 6, 183.

Grassmann, W. (1951). Naturwissenschaften, 38, 200.

Kawerau, E. (1954). Analyst, 79, 681.

Kunkel, H. G., and Tiselius, A. (1951). J. gen. Physiol., 35, 89. 